\title{
The cAMP signaling system regulates LH $\beta$ gene expression: roles of early growth response protein-1, SP1 and steroidogenic factor-1
}

\author{
C D Horton and L M Halvorson \\ Division of Reproductive Endocrinology, Department of Obstetrics and Gynecology, University of Texas Southwestern Medical Center, Dallas, \\ Texas 75390-9032, USA \\ (Requests for offprints should be addressed to L M Halvorson; Email: Lisa.Halvorson@ UTSouthwestern.edu)
}

\begin{abstract}
Expression of the gonadotropin genes has been shown to be modulated by pharmacological or physiological activators of both the protein kinase $C$ (PKC) and the CAMP second messenger signaling pathways. Over the past few years, a substantial amount of progress has been made in the identification and characterization of the transcription factors and cognate cis-elements which mediate the PKC response in the LH $\beta$-subunit $(\mathrm{LH} \beta)$ gene. In contrast, little is known regarding the molecular mechanisms which mediate CAMP-mediated regulation of this gene. Using pituitary cell lines, we now demonstrate that rat $\mathrm{LH} \beta$ gene promoter activity is stimulated following activation of the cAMP system by the adenylate cyclase activating agent, forskolin, or by the peptide, pituitary adenylate cyclase-activating peptide. The forskolin response was eliminated with mutation of a previously identified $3^{\prime}$ cis-acting element for the early growth response protein-1 (Egr-1) when evaluated in the context of region $-207 /+5$ of the LH $\beta$ gene. Activation of the CAMP system increased Egr-1 gene promoter activity, Egr-1 protein levels and Egr-1 binding to the $\mathrm{LH} \beta$ gene promoter, supporting the role of this transcription factor in mediating the cAMP response. Analysis of a longer $\mathrm{LH} \beta$ promoter construct $(-797 /+5)$ revealed additional contribution by upstream Sp1 DNA-regulatory regions. Of interest, forskolin-induced stimulation of LH $\beta$ gene promoter activity was observed to increase synergistically with introduction of the transcription factor, steroidogenic factor-1 (SF-1). Although SF-1 is a critical mediator of the cAMP response in other genes, mutation of the SF-1 DNA-binding sites in the rat LH $\beta$ gene did not alter the forskolin response nor did forskolin increase SF-1 protein levels in a gonadotrope cell line. In a further set of experiments, it was determined that forskolin-responsiveness was maintained following mutation of the previously defined homeobox-binding element at position -100 . We conclude that both Egr-1 and Sp1 contribute to cAMP-dependent transcription of the rat LH $\beta$ gene promoter. While SF-1 does not act independently to mediate the cAMP/PKA response, SF-1 is important for magnification of this response.
\end{abstract}

Journal of Molecular Endocrinology (2004) 32, 291-306

\section{Introduction}

The pituitary gonadotropins, luteinizing hormone $(\mathrm{LH})$ and follicle-stimulating hormone (FSH), are critical mediators of sexual development and adult reproductive function. $\mathrm{LH}$ and $\mathrm{FSH}$ consist of a common $\alpha$-subunit linked non-covalently to one of two unique $\beta$-subunits $(\mathrm{LH} \beta$ and $\mathrm{FSH} \beta$ respectively). As would be predicted by their central role in reproductive physiology, expression of the gonadotropin genes is tightly regulated at both the biosynthetic and secretory levels through the complex interaction of hypothalamic, pituitary and gonadally derived factors. These factors, in turn, activate an array of intracellular signaling systems. The hypothalamic factor gonadotropin-releasing hormone $(\mathrm{GnRH})$ has been widely recognized to alter gonadotropin biosynthesis via activation of both the protein kinase $\mathrm{G}(\mathrm{PKG})$ and calcium pathways (Stojilkovic et al. 1994, Garrel et al. 1997, Saunders et al. 1998, Weck et al. 1998). Recent evidence suggests that GnRH may also stimulate 


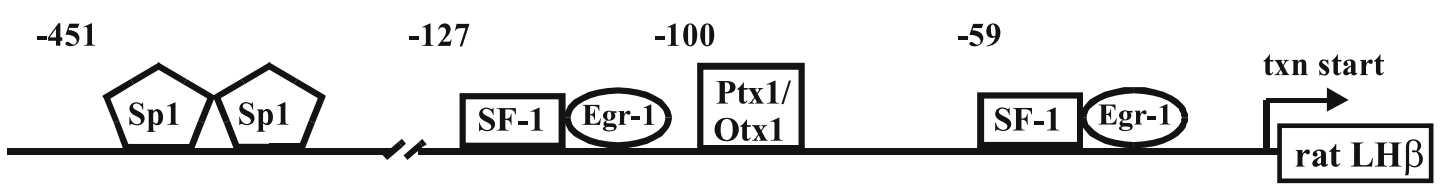

Figure 1 Schematic of identified and putative DNA-regulatory elements in the rat LH $\beta$ gene promoter. Sp1=Sp1; SF-1=steroidogenic factor $-1 ;$ Egr-1=early growth response protein-1; Ptx1=pituitary homeobox 1; Otx=orthodenticle-related homeobox (Ingraham et al. 1994, Halvorson et al. 1996, 1998, Kaiser et al. 1998, Tremblay et al. 1998, Rosenberg \& Mellon 2002).

the cAMP/protein kinase A (PKA) signaling system 3 (Stanislaus et al. 1994, Liu et al. 2002). Gonadotropin gene expression is further modulated by additional hypothalamic peptides, including pituitary adenylate-cyclase activating peptide (PACAP). PACAP is a member of the vasoactive intestinal peptide/secretin/glucagon family of peptides. As its name suggests, PACAP activates the cAMP/PKA system by binding to specific cellsurface G-protein coupled receptors (Miyata et al. 1989, Schomerus et al. 1994, Tsujii et al. 1994).

A number of studies have pointed towards a role for the cAMP/PKA system in modulating expression of the LH $\beta$ gene. In early investigations, pharmacological activation of the adenylate cyclase system was shown to increase steady-state LH $\beta$ mRNA levels (Starzec et al. 1986, 1989). This cAMP-induced increase was blocked by the transcriptional inhibitor, actinomycin $\mathrm{D}$, consistent with an effect of this signaling system on LH $\beta$ gene promoter activity (Park et al. 1997). In subsequent experiments, which utilized the somatolactotrope $\mathrm{GH}_{3}$ cell line, LH $\beta$ gene promoter activity was reported to be increased by cell-permeable cAMP analogues and by the adenylate-cyclase activating agent, forskolin; however, these observations were not confirmed in gonadotrope cells (Clayton et al. 1991, Saunders et al. 1998). Together, these results strongly suggest the presence of a cAMP-inducible regulatory element(s) in the LH $\beta$ gene promoter; however, no subsequent progress has been made in identifying this site(s). This lack of progress contrasts with the advances achieved in the characterization of the transcription factors which are critical for basal and GnRH-stimulated expression of the LH $\beta$ gene in a variety of species (Fig. 1). The DNA-binding sites for three of these transcription factors, steroidogenic factor-1 (SF-1), early growth response protein-1 (Egr-1) and $\mathrm{Sp1}$, form a tripartite response element in the rat $\mathrm{LH} \beta$ gene promoter which confers
GnRH-responsiveness (Kaiser et al. 2000). Interestingly, each of these transcription factors has been implicated in mediating cAMP-responsiveness in other genes.

Egr-1, also known as zif/268, Krox-24 and NGFI-A, is a member of the immediate early response gene family whose members are highly regulated by a variety of growth and differentiation factors (Christy et al. 1988, Cao et al. 1990). Two groups have demonstrated that targeted disruption of the Egr-1 gene in mice results in specific loss of LH $\beta$ gene expression with maintenance of normal FSH $\beta$ gene expression (Lee et al. 1996, Topilko et al. 1997). Experiments by our laboratory and others have demonstrated the ability of Egr-1 to transactivate the LH $\beta$ gene promoter alone and in synergy with SF-1 via two Egr-1 binding sites, which form DNA-regulatory pairs with the SF-1 cis-elements, also known as the gonadotropespecific elements (GSEs) (Lee et al. 1996, Halvorson et al. 1998, Wolfe \& Call 1999). Egr-1 gene expression is markedly increased by $\mathrm{GnRH}$ or phorbol ester treatment of pituitary cell lines, consistent with a role for Egr-1 in mediating PKC-induced stimulation of LH $\beta$ gene expression (Dorn et al. 1999, Halvorson et al. 1999, Wolfe \& Call 1999). Egr-1 gene expression may also be increased by activation of the cAMP/PKA signaling system as suggested by studies in the ovary, as well as non-reproductive systems (BernalMizrachi et al. 2000, Espey et al. 2000, Tai et al. 2001).

The transcription factor, Spl, likewise has been implicated in both basal and GnRH-stimulated expression of the LH $\beta$ gene through action at its two binding sites located $5^{\prime}$ to the SF-1 and Egr-1 cis-acting elements (Kaiser et al. 1998a, Weck et al. 2000). Spl binds to GC-rich sequences, which are similar to, but distinct from, the consensus Egr-1 cis-element (Berg 1992). Constitutively expressed in a wide range of cell types, $\mathrm{Spl}$ is best known as a 
regulator of basal gene transcription; however, cAMP-induced transcription of the CYP11A gene (P450 scc) has been attributed to the presence of an Spl binding site in addition to a GSE (Begeot et al. 1993, Venepally \& Waterman 1995, Liu \& Simpson 1997). It is not known if Spl plays a similar role in mediating the $\mathrm{cAMP} / \mathrm{PKA}$ response in the LH $\beta$ gene.

SF-1, also known as NR5A1, also has been shown to be critical for gonadotropin gene expression. An orphan member of the nuclear hormone receptor superfamily, SF-1/NR5A1 is expressed in the gonadotrope subpopulation of the anterior pituitary gland as well as in the gonads and adrenal gland (Ingraham et al. 1994, Luo et al. 1994). The SF-1 DNA-regulatory region, or GSE, resembles a nuclear hormone receptor half-site and is present as two copies in the LH $\beta$ gene promoter (Barnhart \& Mellon 1994, Halvorson et al. 1998, Wolfe 1999). SF-1 has been implicated in mediating cAMP/PKA responses in a wide variety of gonadal and adrenal genes, including the CYP19 (aromatase), CYP11A (P450 scc), CYP17 and StAR genes (Lynch et al. 1993, Clemens et al. 1994, Michael et al. 1995, Zhang \& Mellon 1996, Carlone \& Richards 1997, Chau et al. 1997, Liu \& Simpson 1997, Jacob \& Lund 1998, Sandhoff et al. 1998). Thus, SF-1, Egr-1 and Spl potentially may all play a role in mediating cAMP-induced expression of the LH $\beta$ gene.

The homeobox cis-element located at position - 100 in the LH $\beta$ gene promoter also

deserves consideration as a potential modulator of cAMP-induced LH $\beta$ gene transcription. This DNA-regulatory region has been shown to bind members of the Ptx (pituitary homeobox) and Otx (orthodenticle-related homeobox) families of homeobox proteins (Tremblay et al. 1998, Rosenberg \& Mellon 2002). Ptxl is required for normal anterior pituitary development as well as for the expression of a broad array of pituitaryspecific genes (Lamonerie et al. 1996, Lanctot et al. 1997, Tremblay \& Drouin 1999, Quirk et al. 2001). Ptxl acts in synergy with Egr-1 and SF-1 to generate GnRH-induced transcriptional activity of the LH $\beta$ gene; however, this effect is thought to be the result of Ptxl interaction with modified transcription factors, particularly Egr-1, rather than through alteration of Ptxl gene expression itself (Tremblay \& Drouin 1999). LH $\beta$ gene expression also has been demonstrated to be regulated by
Otxl and an Otx-related factor may be required for gonadotrope maturation (Acampora et al. 1998, Tremblay et al. 1998, 1999, Rosenberg \& Mellon 2002). Thus, while clearly critical for gonadotrope function, it is unknown whether these homeobox proteins are able to directly mediate hormonal responsiveness.

In summary, substantial progress has been made in the identification of basal and GnRH/PKCresponsive elements in the $\mathrm{LH} \beta$ gene promoter. Limited data from prior studies have suggested that the cAMP/PKA system may also mediate LH $\beta$ gene expression; however, this observation has not been evaluated at the molecular level. In the present study, we demonstrate that activation of the cAMP/PKA system through various methods does, in fact, increase rat $\mathrm{LH} \beta$ gene promoter activity in a gonadotrope-derived cell line. We then investigate the transcriptional mechanisms which mediate this response with a focus on the previously identified LH $\beta$ DNA-regulatory elements for Egr-1, Sp1, SF-1 and Ptx1/Otx.

\section{Materials and methods}

\section{Electrophoretic mobility shift assay (EMSA) analysis}

The nucleotide sequence of the rat LH $\beta$ gene promoter is based on sequencing data available at GenBank accession number AF020505, which differs slightly from that of Jameson et al. (1984). Probes were created by T4 polynucleotide kinase end-labeling with $\left[\gamma_{-}{ }^{32} \mathrm{P}\right] \mathrm{ATP}$ followed by purification over a NICK column (Pharmacia Biotech, Uppsala, Sweden). A double-stranded oligonucleotide corresponding to region $-67 /$ -35 of the rat LH $\beta$ gene promoter was used to detect Egr-1 DNA-binding (Halvorson et al. 1998, 1999).

In vitro-translated Egr-1 was generated from $3 \cdot 2 \mathrm{~kb}$ of the mouse Egr-1 cDNA (provided by D Nathans, Johns Hopkins University, Baltimore, MD) using the TNT Coupled Reticulocyte Lysate System (Promega, Madison, WI, USA). The resultant product was determined to be of appropriate size by comparison with $\left[{ }^{35} \mathrm{~S}\right]$ methionine-labeled protein markers using SDS-PAGE. The method of Andrews \& Faller (1991) was used to prepare crude nuclear extracts from the mouse gonadotrope-derived cell line, 
aT3-1, or the rat somatolactotrope cell line, $\mathrm{GH}_{3}$, following treatment with vehicle or forskolin for $1 \mathrm{~h}$. Protein samples were incubated with 50000 c.p.m. of oligonucleotide probe in DNA-binding

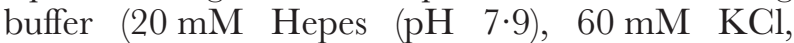
$5 \mathrm{mM} \quad \mathrm{MgCl}_{2}, \quad 10 \mathrm{mM}$ phenylmethylsulfonylfluoride, $10 \mathrm{mM}$ dithiothreitol, $1 \mathrm{mg} / \mathrm{ml} \mathrm{BSA}$ and $5 \% \quad(\mathrm{v} / \mathrm{v})$ glycerol) for $30 \mathrm{~min}$ on ice. Where indicated, $1 \mathrm{ml}$ Egr-1 polyclonal antisera (sc-110; Santa Cruz Biotechnology, Inc., Santa Cruz, CA, USA) was added $30 \mathrm{~min}$ following the addition of probe and the incubation continued for $2 \mathrm{~h}$. Protein-DNA complexes were resolved on a $5 \%$ non-denaturing polyacrylamide gel in $0.5 \times$ Tris-borate-EDTA buffer and subjected to autoradiography.

\section{Plasmids used in transfection studies}

The largest LH $\beta$ reporter construct used for these studies contained $794 \mathrm{bp}$ of the $5^{\prime}$-flanking sequence of the rat LH $\beta$ gene and the first $5 \mathrm{bp}$ of the $5^{\prime}$-untranslated region fused to a luciferase reporter gene, pXP2 (Nordeen 1988). Deletions in this construct were created by subcloning PCR products containing the LH $\beta$ promoter sequences into the pXP2 vector using BamHI/HindIII sites which were introduced by the primers (Kaiser et al. 1998b). Mutations were introduced into the LH $\beta$ promoter region using the Transformer SiteDirected Mutagenesis Kit (Clontech Laboratories, Inc., Palo Alto, CA, USA). The SF-1, Egr-1 and Spl, and Otx/Ptx mutations have been described previously and are known to eliminate DNA binding on EMSA (Kaiser et al. 1998a, Halvorson et al. 1999, Rosenberg \& Mellon 2002).

To create GSE4-GH50, an oligonucleotide was designed containing four copies of the 5'-GSE site flanked by BamHI/BglII restriction sites (sense strand: 5'-GATGCTTTTCTGACGTTGTCTGT CTGGCGTCTGACGTTGTCTGTA-3' present as a tandem repeat). This oligonucleotide was inserted upstream of the minimal growth hormone promoter, GH50, in the pXP1 luciferase reporter plasmid (Nordeen 1988, Suen et al. 1994). All reporter constructs were confirmed by dideoxysequencing.

The SF-1 expression vector contains $2 \cdot 1 \mathrm{~kb}$ of the mouse SF-1 cDNA driven by cytomegalovirus (GMV) promoter sequences in the vector, pCMV5 (provided by K L Parker, Southwestern University
School of Medicine, Dallas, TX) (Lala et al. 1992). The $\Delta$ LBD-SF-1 expression vector lacks the ligand-binding domain of SF-1 and was created by excising the SalI-SalI region of the pCMV5-SF-1 vector. The GMV expression vectors encoding the wild-type and constitutively active G-protein $\alpha$-subunit $(\mathrm{G} \alpha \mathrm{S})$ protein were provided by $\mathrm{R}$ Iyengar, Mount Sinai School of Medicine, New York, NY (Chen \& Iyengar 1994). The Egr-1 expression vector was created by cloning $3 \cdot 2 \mathrm{~kb}$ of the mouse Egr-1 cDNA into pCMV5 at BamHI and HindIII restriction sites (Egr-1 cDNA provided by D Nathans, Johns Hopkins University, Baltimore, MD) (Christy et al. 1988). The Egr-luc reporter construct contains $1.2 \mathrm{~kb}$ of the mouse Egr-1 gene promoter sequence cloned into the SalI site of pXP2 (Egr-1 5'-flanking sequence provided by V Sukhatme, Harvard Medical School, Boston, MA) (Sukhatme et al. 1987). The SF-1-luc expression vector contains 1885 bp upstream of the mouse SF-1 transcriptional start site in the vector pLKS $\beta$-LUC and was kindly supplied by Y Sadovsky, Washington University, St Louis, MO (Woodson et al. 1997).

\section{Transfection experiments}

Rat somatolactotrope $\mathrm{GH}_{3}$ cells or mouse gonadotrope-derived LBT2 cells were cultured to $50-70 \%$ confluence in low glucose $\left(\mathrm{GH}_{3}\right)$ or high glucose (L $\beta$ T2) Dulbecco's modified Eagle's medium supplemented with $10 \%$ fetal calf serum (Invitrogen, Carlsbad, CA, USA). The L $\beta$ T2 cell line was generously provided by $\mathrm{P}$ Mellon (University of California, San Diego, CA, USA) (Turgeon et al. 1996). For the $\mathrm{GH}_{3}$ cell line, approximately $5 \times 10^{6}$ cells were suspended in $0 \cdot 4 \mathrm{ml}$ Dulbecco's PBS plus $5 \mathrm{mM}$ glucose with the DNA to be transfected. The cells received a single electrical pulse of $240 \mathrm{~V}$ at a total capacitance of $1000 \mathrm{mF}$ using an Invitrogen Electroporator II apparatus (Invitrogen). $\mathrm{GH}_{3}$ cells received $1.5 \mu \mathrm{g}$ / well of the reporter constructs. As indicated for the $\mathrm{GH}_{3}$ cell line, cells also received $1 \mu \mathrm{g} /$ well of the SF-1 expression vector or an equivalent amount of the appropriate 'empty' expression vector. For the L $\beta$ T2 cell line, cells growing in $3.5 \mathrm{~cm}$ tissue culture wells were transfected with reporter plasmids $(1.5 \mu \mathrm{g} /$ well $)$ using the calcium phosphate precipitation method. Co-transfection with an RSV- $\beta$-galactosidase plasmid $(1 \mu \mathrm{g} /$ well $)$ allowed 
correction for differences in transfection efficiency between wells in all experiments.

Cells were treated with vehicle, forskolin $(2.5 \mu \mathrm{M})$ (Sigma, St Louis, MO, USA), or PACAP-38 (10 nM) (Calbiochem, La Jolla, CA, USA), for 4-6 h starting approximately $40 \mathrm{~h}$ following transfection. In a subset of experiments, cells were treated with the selective PKA inhibitor, $\mathrm{H}-89(10 \mu \mathrm{M})$, or with the PKG inhibitor, GF 109203X $(5 \mu \mathrm{M})$, starting $1 \mathrm{~h}$ prior to DMSO or forskolin treatment (inhibitors obtained through LC Laboratories, Woburn, MA, USA). Cells were then harvested and the cell extracts analyzed for luciferase and $\beta$-galactosidase activity (Edlund $e t$ al. 1985, deWet et al. 1987). Luciferase activity was normalized to the level of $\beta$-galactosidase activity and results calculated as fold-change relative to expression in the control wells. Data are shown as the means \pm S.E.M. from three to ten independent experiments.

\section{Western blot analysis}

Nuclear extracts were obtained from L $\beta$ T2 cells as described by Tremblay et al. (1998). Protein concentration were determined using the BCA protein assay reagent (Pierce Chemical, Rockford, IL, USA). In vitro-translated Egr-1 and SF-1 were generated using the TNT Coupled Reticulocyte Lysate System (Promega) as described for EMSA. Nuclear proteins $(5 \mu \mathrm{g})$ were resolved on a $10 \%$ SDS-PAGE in $25 \mathrm{mM}$ Tris/250 mM glycine (TG) buffer. The protein was subsequently transferred onto $0.2 \mu \mathrm{M}$ Protran nitrocellulose (Schleicher \& Schuell, Keene, NH, USA) in TG buffer containing $20 \%$ methanol. The membrane was blocked overnight at $4{ }^{\circ} \mathrm{C}$ in $5 \%$ Carnation non-fat dry milk in TBS $(10 \mathrm{mM}$ Tris-HCl, 0.9\% NaCl, pH 7.5) and then washed with TBS-T (TBS, 0.05\% Tween-20). The blot was incubated overnight at $4{ }^{\circ} \mathrm{C}$ in $5 \%$ milk-TBS with a polyclonal antibody directed against SF-1 (Upstate Biotechnology, Inc., Lake Placid, NY, USA) or Egr-1 (Santa Cruz Biotechnology), diluted to $1: 1000$ or $1: 8000$ respectively. After washing with TBS-T, the blot was then incubated at room temperature for $1 \mathrm{~h}$ in $5 \%$ milk in TBS-T containing donkey anti-rabbit IgG-horseradish peroxidase diluted 1:1000 (Santa Cruz Biotechnology). The blot was washed with TBS-T and then TBS and developed using Western Blotting Luminol Reagent according to the manufacturer's instructions (Santa Cruz Biotechnology).

\section{Statistical analysis}

ANOVA followed by comparisons with Student's $t$-test was used to assess whether promoter activity was statistically different between the indicated groups. Statistical significance was set at the $P<0.05$ level.

\section{Results}

\section{Activation of the cAMP/PKA signaling system stimulates LH $\beta$ gene expression in two pituitary cell lines}

Transfection experiments were performed in two pituitary cell lines, a gonadotrope-derived cell line $(\mathrm{L} \beta \mathrm{T} 2)$ and a somatolactotropic cell line $\left(\mathrm{GH}_{3}\right)$. L $\beta$ T2 cells were transiently transfected with a reporter construct containing region $-794 /+5$ of the rat LH $\beta$ gene promoter. Cells were treated with PACAP, a known physiological activator of the cAMP/PKA system in gonadotrope cells. As shown in Fig. 2A, PACAP treatment modestly, but significantly, increased LH $\beta$ gene promoter activity relative to control wells (2-fold). Although PACAP is best known for activation of the cAMP/PKA system, it also has been shown to stimulate the phospholipase G (PLC) and calcium pathways (Schomerus et al. 1994, Hezareh et al. 1996, Pisegna \& Wank 1996, Bresson-Bepoldin et al. 1998). Therefore, in order to more specifically investigate the cAMP system, cells were treated with forskolin, a pharmacological activator of adenylate cyclase. As observed with PACAP treatment, luciferase activity was stimulated with the addition of forskolin (1-8-fold).

The ability of forskolin to augment LH $\beta$ gene promoter activity was also investigated in $\mathrm{GH}_{3}$ cells. $\mathrm{GH}_{3}$ cells have been used extensively to study gonadotropin gene regulation and have been found to provide qualitatively accurate observations with regards to both basal and hormonally regulated LH $\beta$ gene expression (Kim et al. 1990, Clayton et al. 1991, Kuphal et al. 1994, Stanislaus et al. 1994, Saunders et al. 1998, Pinter et al. 1999). This cell line lacks endogenous SF-1, thereby permitting independent analysis of the effects of signaling pathways and SF-1 (Kaiser et al. 1994, Halvorson et al. 1998). 
As shown in Fig. 2B, LH $\beta$ gene promoter activity was significantly increased with forskolin treatment or in the presence of a constitutively active mutant form of the GaS protein (3- and 2-fold respectively). Co-transfection with the GMVdriven SF-1 expression vector resulted in a 15-fold increase in luciferase activity, consistent with previously published results (Halvorson et al. 1998). Of interest, $\mathrm{LH} \beta$ promoter activity increased by nearly 50-fold in the presence of SF-1 and either

A

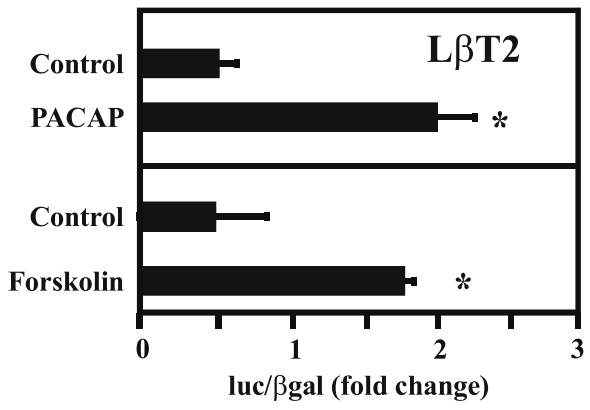

B

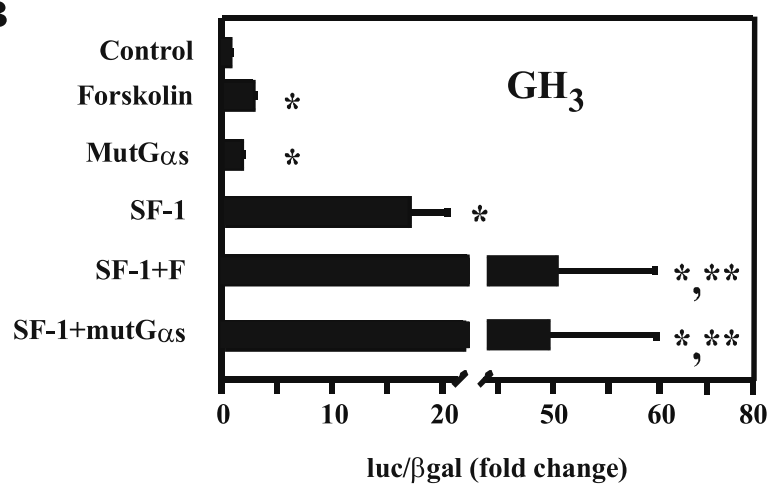

C

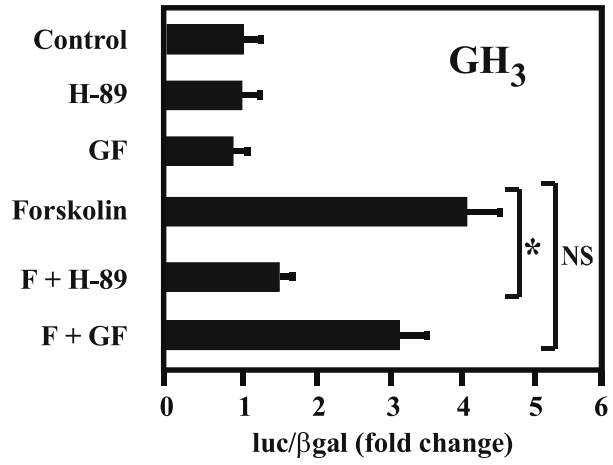

forskolin or the mutant GaS, demonstrating synergy between SF-1 and cAMP signaling.

We next used pharmacological inhibitors in order to formally test the specificity of forskolin in our system. As shown in Fig. 2C, neither the PKA blocking agent, H-89, nor the PKC inhibitor, GF 109203X, altered basal LH $\beta$-driven luciferase activity. However, the forskolin-stimulated increase in LH $\beta$ promoter activity was significantly blunted by H-89, but not by GF 109203X, consistent with a specific effect of forskolin on the cAMP/PKA activity.

\section{The LH $\beta$ gene promoter contains two regions which contribute to the CAMP/PKA response}

Sequential 5'-deletion constructs of the rat $\mathrm{LH} \beta$ gene promoter were tested for forskolinresponsiveness. This analysis identified two regions which contribute to the forskolin response, the first

Figure 2 The cAMP/PKA system acts both alone and in synergy with SF-1 to increase $\mathrm{LH} \beta$ gene promoter activity. (A) L $\beta T 2$ gonadotrope cells were transiently transfection with $-794 /+5$ rat $\mathrm{LH} \beta$ gene promoter linked to a luciferase reporter construct, pXP2. Cells were treated for 4-6 $\mathrm{h}$ with PACAP-38 (10 nM), forskolin $(2.5 \mu \mathrm{M})$ or the appropriate vehicle and harvested $48 \mathrm{~h}$ following transfection. Results are shown as the means \pm S.E.M. of eight experiments. ${ }^{*} P<0.01$ vs control. (B) $\mathrm{GH}_{3}$ cells were transiently transfected with region $-207 /+5$ of the rat $\mathrm{LH} \beta$ gene promoter linked to a luciferase reporter construct, pXP2. A subset of cells also received CMV-driven expression vectors encoding SF-1 and/or a constitutively active $\mathrm{G} \alpha \mathrm{S}$ protein. Control wells received equivalent amounts of 'empty' expression vector. All cells were co-transfected with an RSV- $\beta$-galactosidase vector. Approximately $40 \mathrm{~h}$ after transfection, cells were treated for $4-6 \mathrm{~h}$ with vehicle or with the adenylate cyclase activating agent, forskolin. Luciferase activity was normalized to $\beta$-galactosidase activity and promoter activity was calculated as fold-change over expression in the control wells. Results are shown as the means \pm S.E.M. of four independent experiments. ${ }^{*} P<0.01$ vs control; ${ }^{* \star} P<0.05$ vs SF- 1 alone. (C) A luciferase reporter construct containing region $-797 /+5$ of the rat $\mathrm{LH} \beta$ gene promoter was transiently transfected into $\mathrm{GH}_{3}$ cells, followed by treatment with vehicle or $2.5 \mu \mathrm{M}$ forskolin for 4-6 h starting $40 \mathrm{~h}$ after transfection. Where indicated, cells received the PKA inhibitor, $\mathrm{H}-89$, or the PKC blocking agent GF 109203X, beginning $1 \mathrm{~h}$ prior to the addition of forskolin. Results are shown as the means \pm S.E.M. of three independent experiments. ${ }^{*} P<0.001$ vs forskolin; NS $=$ not significant, $P>0.05$ vs control. 


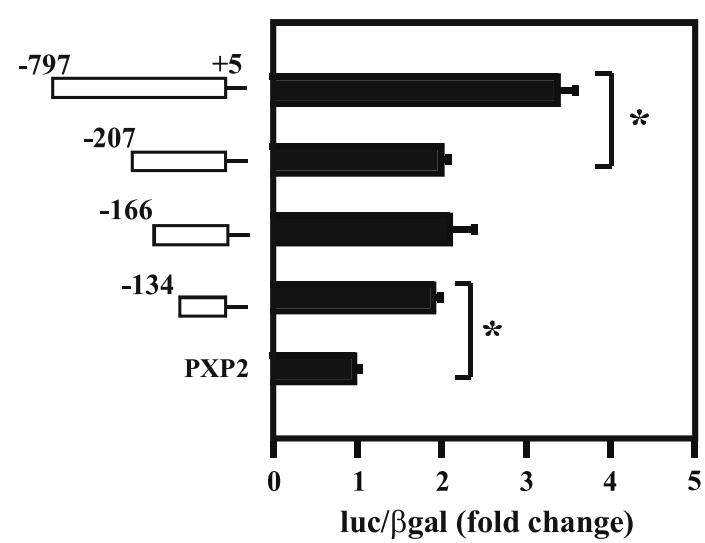

Figure 3 Stepwise loss of forskolin-responsiveness with sequential $5^{\prime}$-deletion of the $\mathrm{LH} \beta$ gene promoter. $\mathrm{GH}_{3}$ cells were transiently transfected with varying regions of the rat $\mathrm{LH} \beta$ gene promoter in the luciferase reporter vector, pXP2. Cells were treated with vehicle or $2.5 \mu \mathrm{M}$ forskolin for 4-6 h starting $40 \mathrm{~h}$ after transfection. Luciferase activity was normalized to RSV-driven $\beta$-galactosidase activity and promoter activity was calculated as fold-change over expression in the control wells. Results are shown as the means \pm S.E.M. Each construct was tested in between three and ten experiments with points run in triplicate. ${ }^{\star} P<0.001$.

between positions -797 and -207 and the second between position -134 and the transcriptional start site (Fig. 3).

\section{Loss of the cAMP/PKA response with mutation of the Egr-1 binding sites}

Pharmacological or hormonal activation of the cAMP/PKA signaling system has been reported to increase Egr-1 gene expression (mRNA and/or protein levels) in the ovary and in pheochromocytoma and insulinoma cell lines (Bernal-Mizrachi et al. 2000, Espey et al. 2000, Tai et al. 2001). We hypothesized that cAMP-responsiveness of the LH $\beta$ gene may be mediated likewise by Egr-1 acting through previously identified Egr-1 ciselements in this gene. As shown in Fig. $4, \mathrm{GH}_{3}$ cells were transfected with a $-207 /+5$ rat LH $\beta$ gene reporter construct present as the wild-type construct or with mutations in one or both of the Egr-1 DNA-binding sites. We have previously demonstrated that in vitro-translated Egr-1 is unable to bind to oligonucleotide probes harboring analogous mutations (Halvorson et al. 1998). Mutation of the 3'-Egr-1 site eliminated the forskolin response,

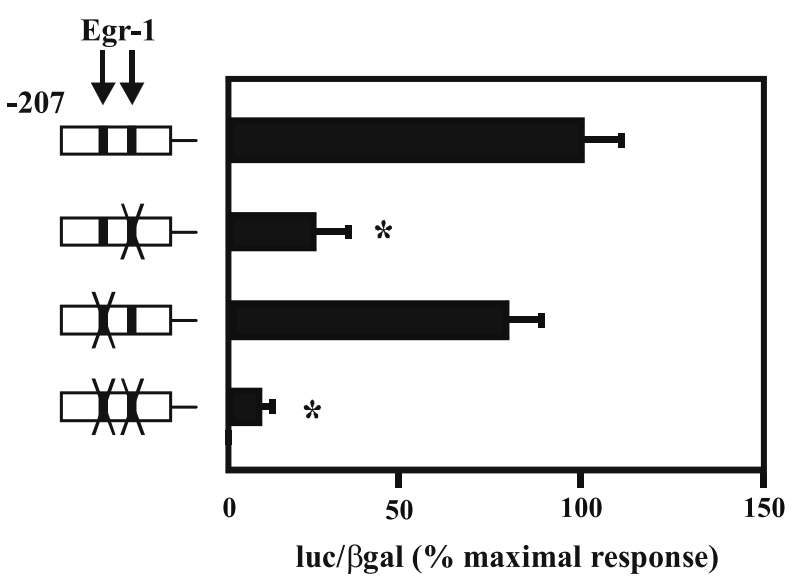

Figure 4 Loss of the cAMP/PKA response with mutation of the Egr-1 binding sites. Transient transfection was performed in $\mathrm{GH}_{3}$ cells using luciferase reporter constructs containing region $-207 /+5$ of the rat LH $\beta$ gene promoter present as either the wild-type sequence or with mutations in one or both of the previously characterized Egr-1 DNA cis-elements. Cells were treated as in Fig. 2. The results are presented relative to the forskolin response of the wild-type construct, which has been set at $100 \%$. Data given as the means \pm S.E.M. of three independent experiments. ${ }^{\star} P<0.01$ vs wild-type.

while mutation of the $5^{\prime}$ site had no effect. Although mutation of both Egr-1 cis-elements further reduced the response, this result was not statistically different than the response in the 3 '-Egr mutant construct.

\section{The forskolin response is not attributable to the presence of SF-1 or its cognate cis-elements (GSEs) in the LH $\beta$ gene promoter}

The proximal forskolin-responsive region identified in Fig. 3 was also noted to contain previously characterized DNA-regulatory elements for the orphan nuclear receptor, SF-1. It is clear that SF-1 cannot be implicated in the ability of forskolin treatment alone to increase LH $\beta$ gene promoter activity in the SF-1-deficient $\mathrm{GH}_{3}$ cell line. Nevertheless, as ultimate interest is in the physiological regulation of gonadotrope function, it is critical to determine whether SF-1 and its associated cis-elements are involved in the observed cAMP-dependent transcription of the LH $\beta$ gene. SF-1 has been demonstrated to be crucial for mediating cAMP/PKA-induced increases in the 
transcription a variety of genes encoding enzymes in the steroidogenesis pathway (Lynch et al. 1993, Clemens et al. 1994, Michael et al. 1995, Zhang \& Mellon 1996, Carlone \& Richards 1997, Chau

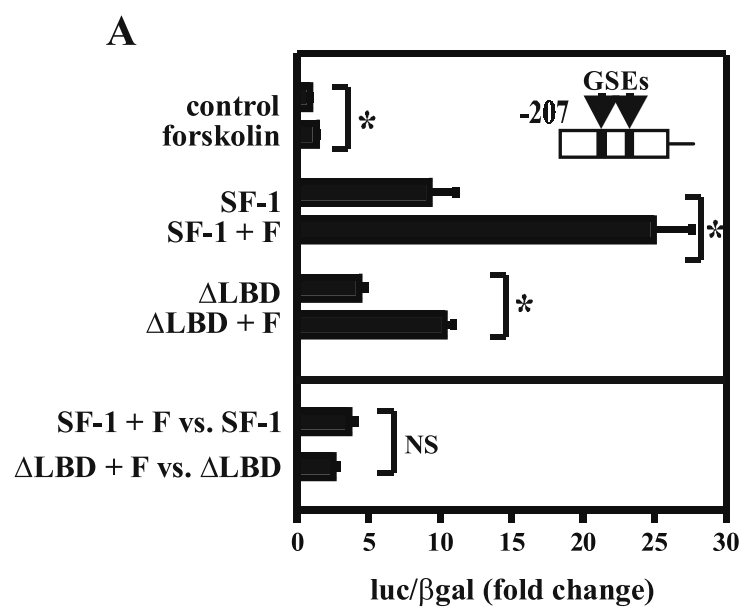

B

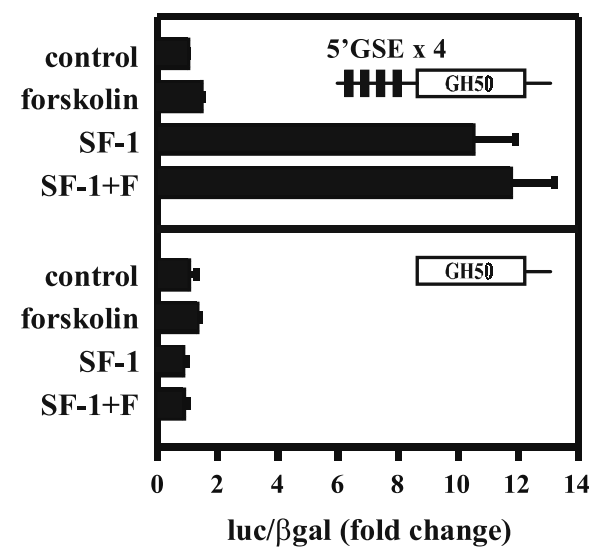

C

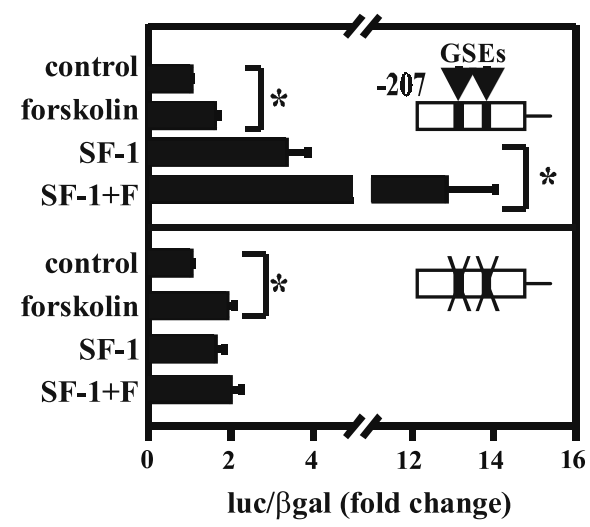

et al. 1997, Liu \& Simpson 1997, Jacob \& Lund 1998, Sandhoff et al. 1998). In a number of these studies, alterations in SF-1 transactivation efficiency have been attributed to cAMP-dependent phosphorylation of the AF-2 domain of SF-1 (Crawford et al. 1997, Jacob \& Lund 1998).

We therefore investigated whether the interaction between forskolin and SF-1 was altered with deletion of the SF-1 ligand-binding domain containing the AF-2 domain. As shown in Fig. 5A, the presence of the carboxy-truncated SF-1 construct $(\triangle \mathrm{LBD})$ markedly increased LH $\beta$ promoter activity, although to a lesser extent than observed with the native SF-1 (4- vs 9-fold respectively). The addition of forskolin further stimulated LH $\beta$ gene expression in the presence of either SF-1 construct (upper panel). The data were recalculated to evaluate whether the magnitude of the forskolin response differed depending on which SF-1 construct was present. As shown in the lower panel, the fold-change in $\mathrm{LH} \beta$ promoter activity was not significantly different between constructs

Figure 5 Role of SF-1 and associated DNA-regulatory elements (GSEs) in mediating cAMP/PKA-responsiveness of the LH $\beta$ gene promoter. $\mathrm{GH}_{3}$ cells were transiently transfected with various rat $\mathrm{LH} \beta$ gene promoter reporter constructs. Cells were co-transfected with CMV-driven SF-1 expression vectors or control 'empty' vectors as well as the RSV- $\beta$-galactosidase vector. Prior to harvesting, cells received $2.5 \mu \mathrm{M}$ forskolin or vehicle for 4-6 h starting $40 \mathrm{~h}$ after transfection. Results are shown as the means \pm S.E.M. of three to eight experiments with each data point tested in triplicate. ${ }^{*} P<0.001$; NS $=$ not significant, $P>0.05$. (A) Comparison of the forskolin (F) effect in the presence of CMV-driven expression vectors encoding the full-length vs a carboxy-truncated SF-1 mutant lacking the ligand binding domain $(\Delta L B D)$. Promoter activity was calculated as fold-change relative to control wells (upper panel). Alternatively, data was expressed as the response to forskolin treatment in the presence of the intact or the truncated SF-1 vs the response to forskolin treatment alone (lower panel). (B) PKA effects in a heterologous LH $\beta$-GSE-promoter construct. $\mathrm{GH}_{3}$ cells were transiently transfected with a construct containing the growth hormone minimal promoter, GH50, linked to a luciferase reporter construct, pXP1, with or without the addition of four copies of the 5'-GSE site. (C) Maintenance of the forskolin response following mutation of the SF-1 binding sites (GSEs). $\mathrm{GH}_{3}$ cells were transfected with region $-207 /+5$ of the rat $\mathrm{LH} \beta$ gene promoter present as either the wild-type sequence or with mutations in both GSE sites. 
(approximately 3-fold with either construct), suggesting that the observed synergy between SF-1 and the cAMP system is not dependent on alterations at the carboxy-terminus of the SF-1 molecule.

A

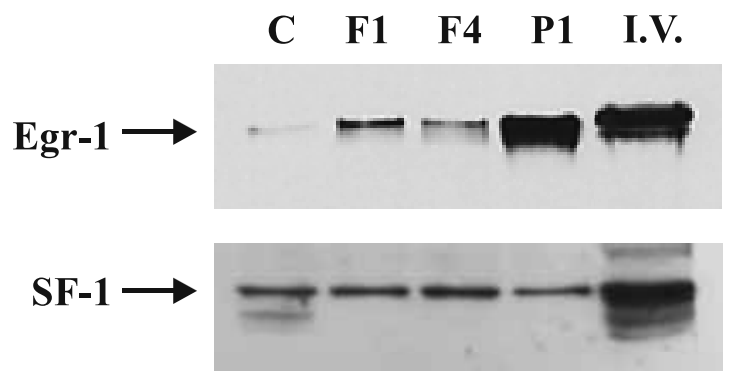

B

$\begin{array}{llll}C & \text { F1 } & \text { F4 } & \text { P1 }\end{array}$

Egr-1

\begin{tabular}{|cccc|}
\hline 1.0 & 16 & 11 & 70 \\
\hline 1.0 & 1.0 & 1.2 & 0.7 \\
\hline
\end{tabular}

C SF-1

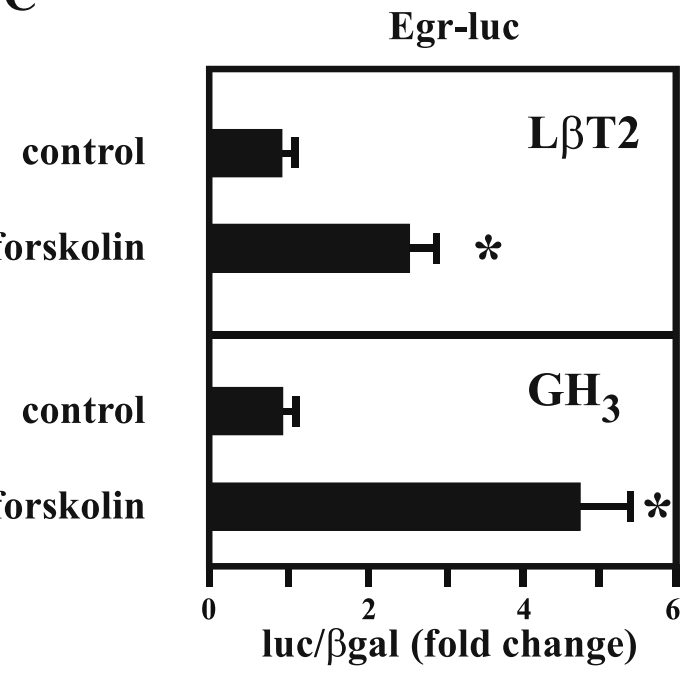

As an alternative approach, we reasoned that a forskolin response should be observed in the presence of SF-1 DNA-regulatory elements if, in fact, activation of the cAMP/PKA system is directly altering SF-1 functional activity. Four copies of the rat LH $\beta$ 5'-GSE sequence were inserted upstream of the growth hormone minimal promoter, GH50, in the $\mathrm{pXP1}$ reporter vector. As seen in Fig. 5B, these sequences conferred an SF-1 response, but failed to confer a response to forskolin (10.5- and 11.8-fold for SF-1 alone and SF-1 plus forskolin respectively).

These results suggest that the cAMP/PKA effect is unlikely to be due to direct effects on the transcription factor, SF-1. This conclusion was confirmed by transfecting cells with a construct containing point mutations in both GSE sites within the context of the native rat LH $\beta$ gene promoter. These mutations have been shown to eliminate SF-1 DNA-binding and SF-1-induced transactivation (Halvorson et al. 1998). In contrast to the loss of the response to SF-1, forskolininduced stimulation was conserved in the mutated construct (1.9- vs 1.8-fold in the wild-type construct) (Fig. 5C). These data strongly suggest that SF-1 and its cognate cis-element are not required for mediating the cAMP response in the rat $\mathrm{LH} \beta$ gene promoter.

Figure 6 Activation of the cAMP/PKA system induces Egr-1 gene expression. (A) Cells from the gonadotrope-derived cell line, $\mathrm{L} \beta \mathrm{T} 2$, were treated with a vehicle control (lane C), $2.5 \mu \mathrm{M}$ forskolin for $1 \mathrm{~h}$ (lane $\mathrm{F} 1$ ) or $4 \mathrm{~h}$ (lane F4), or with $100 \mathrm{ng} / \mathrm{ml} \mathrm{PMA} \mathrm{for} 1 \mathrm{~h}$ (lane P1). Nuclear proteins $(5 \mu \mathrm{g})$ or in vitro-translated Egr-1 or SF-1 were then separated on 10\% SDS-PAGE gels followed by chemiluminescent Western blot analysis. I.V., in vitro translated Egr-1. (B) Band intensity from $(A)$ was quantified using a Kodak EDAS 290 Image Analysis station and calculated as fold-change relative to vehicle-treated cell extracts. (C) $\mathrm{L} \beta \mathrm{T} 2$ or $\mathrm{GH}_{3}$ cells were transiently transfected with a luciferase reporter construct containing $1.2 \mathrm{~kb}$ of the $5^{\prime}$-flanking region of the Egr-1 gene. An RSV- $\beta$-galactosidase vector was co-transfected to control for transfection efficiency. Cells were treated with vehicle or $2.5 \mu \mathrm{M}$ forskolin for $4 \mathrm{~h}$ prior to harvesting at $48 \mathrm{~h}$ post-transfection. Following normalization to $\beta$-galactosidase activity, promoter activity was calculated as fold-change in luciferase activity in treated vs untreated wells. Results are shown as the means \pm S.E.M. of five independent experiments. ${ }^{*} P<0.001$. 


\section{Activation of the CAMP/PKA signaling system} induces Egr-1, but not SF-1, gene expression

Results from experiments presented in Figs 4 and 5 suggest that the cAMP/PKA signaling system acts via Egr-1, but not SF-1, to stimulate LH $\beta$ gene expression. In order to further evaluate these observations, we asked whether activation of the cAMP system altered Egr-1 and/or SF-1 protein expression in gonadotrope cells. As shown by Western blot analysis in Fig. 6A and B, treatment of gonadotrope L $\beta$ T2 cells with $2.5 \mu \mathrm{M}$ forskolin markedly increased Egr-1 protein levels, but did not alter SF-1 protein levels in this protocol. The observed induction of Egr-1 protein expression by the phorbol ester, phorbol 12-myristate 13-acetate (PMA), is consistent with previous reports (Dorn et al. 1999).

The observed increase in Egr-1 protein levels may be due to increased Egr-1 biosynthesis and/ or post-translational modification, resulting in increased protein stability. In order to determine whether activation of the cAMP pathway system altered Egr-1 biosynthesis, pituitary cell lines were transiently transfected with a luciferase reporter construct containing $1.2 \mathrm{~kb}$ of the Egr-1 gene promoter. Forskolin treatment increased Egr-1 promoter activity nearly 3 -fold in the L $\beta$ T 2 cell line, with a 4-fold increase in the line $\mathrm{GH}_{3}$ cells (Fig. 6C). In contrast, SF-1 promoter activity was not regulated by forskolin in the $\mathrm{GH}_{3}$ cell line (data not shown).

We next used EMSA to determine whether increased Egrl gene expression results in altered Egr-1 DNA-binding to the rat LH $\beta$ gene promoter. Nuclear extracts from untreated $\mathrm{GH}_{3}$ or gonadotrope $\alpha \mathrm{T} 3-1$ cells formed a single dominant band with an oligonucleotide probe spanning the 3'-Egr-1 site (Fig. 7B, lanes 2 and 7). Prior studies utilizing specific antibodies have demonstrated the presence of the transcription factor, Spl, in this complex (Halvorson et al. 1999). The addition of forskolin $(2.5$ or $25 \mu \mathrm{M} \times 1 \mathrm{~h})$ induced a faster migrating complex (lanes 3, 5, 8 and 10) that contained Egr-1 as shown by the addition of an Egr-1-specific antibody (lanes 4, 6, 9 and 11). The similar mobility of in vitro-translated Egr-1 (lane 1) was consistent with the presence of Egr-1 in the treated extracts.

Taken together, these results suggest that the cAMP signaling system induces Egr-1 transacti-

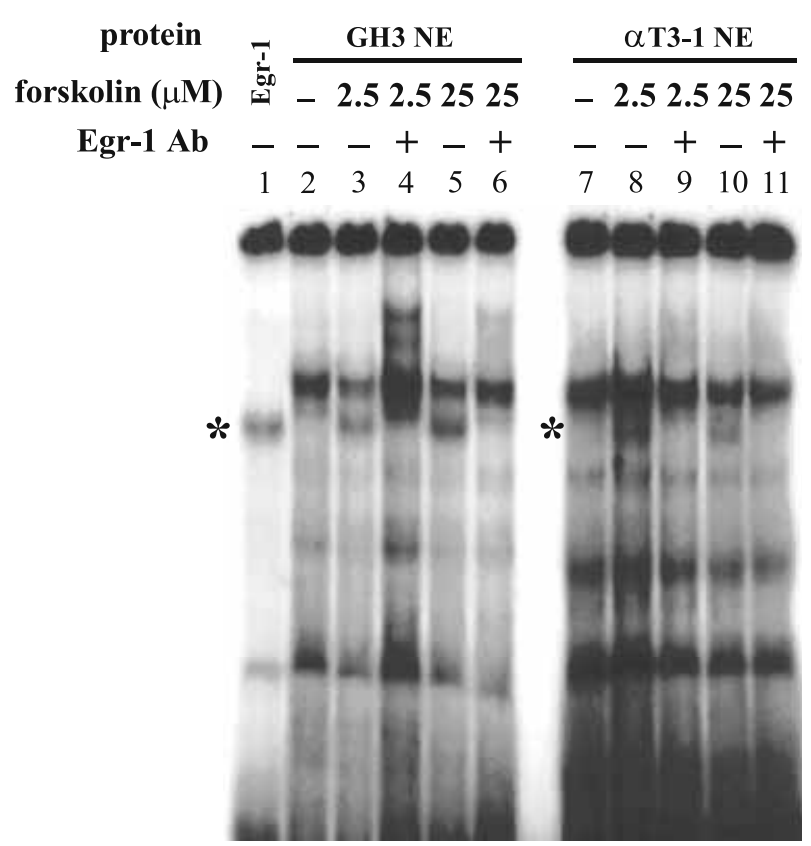

Figure 7 Forskolin treatment induces Egr-1 binding to rat $\mathrm{LH} \beta$ gene promoter sequences. Activation of the cAMP/PKA system induces Egr-1 gene expression. EMSA was performed using in vitro-translated Egr-1 (lane 1) or nuclear extracts from $\mathrm{GH}_{3}$ cells (left panel) or from the gonadotrope-derived $\alpha \mathrm{T} 3-1$ cell line (right panel). Nuclear extracts were derived from cells maintained in the absence or presence of forskolin (2.5 or $25 \mu \mathrm{M}$ for $1 \mathrm{~h}$ ). Region $-67 /-35$ of the rat $\mathrm{LH} \beta$ gene promoter containing the $3^{\prime}$-Egr-1-binding site was ${ }^{32} \mathrm{P}$ labeled and used as a probe. Where indicated, antiserum specific for Egr-1 was added $2 \mathrm{~h}$ prior to electrophoresis. $\mathrm{NE}=$ nuclear extract; * indicates Egr-1-containing complex.

vation capability, at least in part, via increased biosynthesis of the Egr-1 gene.

\section{Sp1 DNA-binding sites contribute to the full forskolin response of the $-797 /+5 \mathrm{LH} \beta$ gene promoter region}

We then tested the importance of the Egr-1 cis-elements for cAMP/PKA-responsiveness in the context of a longer region of the rat $\mathrm{LH} \beta$ gene 5 -flanking sequence $(-797 /+5)$. As shown in Fig. 8 , the forskolin effect was significantly blunted with the introduction of point mutations into the Egr-1 sites. Nevertheless, a substantial response remained in the mutant promoter constructs suggesting the presence of a non-Egr-1, PKA-responsive regulatory region in the more distal $\mathrm{LH} \beta$ gene promoter. 


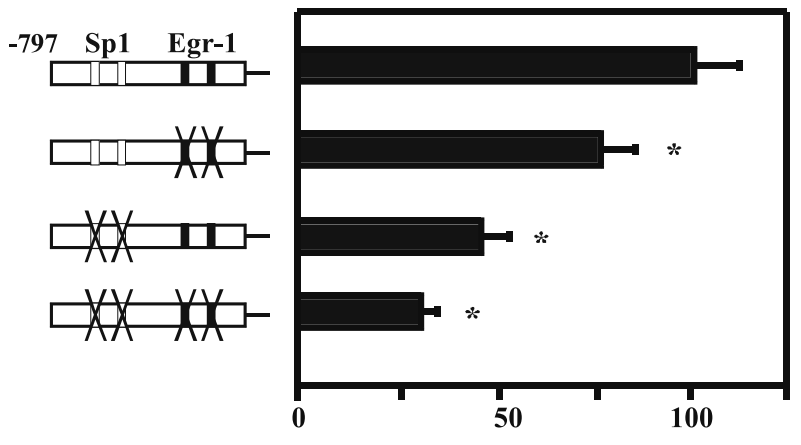

luc/ $\beta$ gal ( $\%$ maximal response)

Figure 8 Both Egr-1 and Sp1 DNA-binding sites contribute to the full cAMP response of region $-797 /+5$ of the $\mathrm{LH} \beta$ gene promoter. $\mathrm{GH}_{3}$ cells were transiently transfected with region $-797 /+5$ of the rat $\mathrm{LH} \beta$ gene promoter present as the wild-type sequence or with mutations in the previously described Egr-1 and Sp1 cis-elements. Forskolin treatment and data calculation were as described in Fig. 5B and represent seven independent experiments. The results are presented relative to the forskolin-response of the wild-type construct, which has been set at $100 \%$. ${ }^{*} P<0.05$ vs wild-type.

Region - 451/-386 of the rat LH $\beta$ gene promoter has been shown to contain two binding sites for the ubiquitous transcription factor, Spl. These sites have been shown to contribute to both basal and GnRH-mediated LH $\beta$ gene expression (Kaiser et al. 1998a). Mutation in the LH $\beta$-Spl sites significantly decreased the forskolin response, with further blunting in a construct containing mutations in both the Spl and Egr-1 cis-elements. These data suggest that both Spl and Egr-1 contribute to the full cAMP response of the - 797/ +5 rat LH $\beta$ gene promoter.

\section{Mutation of the homeodomain cis-element does not alter CAMP-responsiveness in the rat LH $\beta$ gene}

As shown in Fig. 8, a small residual cAMP-response was noted in the $-797 /+5$ rat LH $\beta$ gene promoter construct despite mutation of both the Spl and Egr-1 cis-elements. These results suggested a contribution by a third DNA-regulatory region. In an attempt to identify this site, we analyzed a previously identified homeodomain cis-element located at position -100 in the rat $\mathrm{LH} \beta$ gene promoter. Mutation of this site did not alter the magnitude of the forskolin response, arguing against a role for Ptx/Otx-related proteins in mediating this response (data not shown).

\section{Discussion}

LH $\beta$ gene expression is regulated by the complex interaction of hypothalamic, pituitary and gonadal factors, which in turn activate a variety of intracellular signaling systems. GnRH-induced stimulation of the PKC system has been widely recognized and intensively investigated (Kaiser et al. 1998b, Halvorson et al. 1999, Wolfe \& Call 1999, Weck et al. 2000, Vasilyev et al. 2002). Studies have suggested that gonadotrope function is also mediated by physiological modulators of the cAMP/PKA system. The hypothalamic peptide, PACAP, is perhaps the best studied of these factors. PACAP has been shown to increase cAMP levels in both primary pituitary cells as well as in gonadotrope cell lines (Miyata et al. 1989, Schomerus et al. 1994). Interestingly, GnRH has recently been demonstrated to activate $G_{s}$ protein and increase intracellular cAMP levels in the gonadotrope L $\beta$ T2 cell line, confirming prior studies in $\mathrm{GH}_{3}$ cells stably expressing the GnRH receptor (Stanislaus et al. 1994, Liu et al. 2002). As reported by Ortmann et al. (1999) the gonadal steroid, estradiol, may also modulate adenylate cyclase activity. Furthermore, it is increasingly clear that crosstalk occurs between the PKC and PKA systems in the gonadotrope (McArdle et al. 1994, Garrel et al. 1997). Collectively, these data strongly support the physiological relevance of the cAMP/ PKA pathway in regulating gene expression in gonadotrope cells.

In prior studies, PACAP has been shown to increase gonadotropin secretion and to modulate steady-state $\alpha$-, LH $\beta$ - and FSH $\beta$-subunit mRNA levels (McArdle et al. 1994, Tsujii \& Winters 1995, Winters et al. 1997, Attardi \& Winters 1998, Burrin et al. 1998, Fujii et al. 2002). We now demonstrate PACAP increases LH $\beta$ gene promoter activity in the gonadotrope-derived cell line, L $\beta$ T2 (Fig. 2). These results suggest that increased transcriptional activity contributes to the observed PACAPinduced increase in LH $\beta$ mRNA levels. As previously noted, PACAP stimulates the PLC and calcium pathways in addition to increasing 
intracellular cAMP levels (Schomerus et al. 1994, Hezareh et al. 1996, Pisegna \& Wank 1996, Bresson-Bepoldin et al. 1998). In order to focus our studies on the effects of the cAMP/PKA signaling system, we chose to utilize the specific adenylate cyclase activator, forskolin, for the remainder of our experiments.

Forskolin treatment stimulated LH $\beta$ gene promoter activity in both $\mathrm{L} \beta \mathrm{T} 2$ and $\mathrm{GH}_{3}$ cells (Fig. 2). Forskolin increased Egr-1 promoter activity, protein levels, and Egr-1 binding to the LH $\beta$ gene promoter (Figs 6 and 7). Furthermore, mutation of the 3'-Egr-1 cis-element in the proximal LH $\beta$ gene promoter was observed to blunt the forskolin response (Fig. 4). Based on these data, we propose that $\mathrm{cAMP} / \mathrm{PKA}$-induced stimulation of $\mathrm{LH} \beta$ promoter activity is achieved, in part, through induction of Egr-1 gene expression.

It should be noted that two other groups did not observe a forskolin-mediated increase in steadystate Egr-1 mRNA levels or Egr-1 gene promoter activity using the gonadotrope-derived $\alpha \mathrm{T} 3-1$ cell line (Tremblay \& Drouin 1999, Duan et al. 2002). Interestingly, one of these groups did observe that GnRH-induced increases in Egr-1 transcription and protein levels could be partially abrogated by the PKA blocking agent, $\mathrm{H}-89$, results which support a role for cAMP/PKA in modulating Egr-1 gene function (Duan et al. 2002).

Egr-1 is a member of the immediate early gene family whose members are markedly regulated at the biosynthetic and post-translational level by a wide variety of growth and differentiation factors (Christy et al. 1988, Cao et al. 1990). Forskolin treatment has been shown to increase Egr-1 promoter and protein expression in insulinoma and pheochromocytoma cell lines respectively (BernalMizrachi et al. 2000, Tai et al. 2001). Richards and co-workers (Espey et al. 2000) have shown that Egr-1 mRNA and protein levels are increased by human chorionic gonadotropin (hCG) treatment in ovarian granulosa cells, presumably due to $\mathrm{LH}$ receptor-mediated activation of the cAMP pathway. More recently, Yoshino et al. (2002) demonstrated that both hCG and 8-Br-cAMP increase Egr-1 mRNA levels in luteinized granulosa cells. Thus, current data now exist to suggest that cAMP modulates Egr-1 gene expression at multiple levels of the reproductive axis.

Mutation of the Spl DNA-binding sites further blunted the cAMP response in the context of the longer region of the rat $\mathrm{LH} \beta$ gene promoter (Fig. 8). Constitutively expressed, Spl classically has been thought to act as a basal transcription factor. Nevertheless, recent studies have implicated Spl in the hormonal regulation of a variety of genes, including cAMP-induced transcription of the CIP17 and CYP11A (P450 scc) steroidogenic genes (Begeot et al. 1993, Venepally \& Waterman 1995, Borroni et al. 1997, Ahlgren et al. 1999). The precise mechanism by which Spl mediates the cAMP effect in the rat LH $\beta$ gene remains to be determined. In preliminary studies, forskolin treatment did not alter the intensity of endogenous Spl binding to LH $\beta$-Spl sites, implying that Spl protein levels are not altered (data not shown). Spl is known to be modified by $\mathcal{N}$ - and $O$-linked glycosylation as well as by phosphorylation (Jackson et al. 1990). It has been proposed that these post-translational modifications may alter Spl interactions with other transcription factors, such as SF-1, and/or with specific co-activators including the cAMP-responsive co-factor, CBP/p300 (Liu \& Simpson 1999).

Unlike the highly conserved Egr-1 and SF-1 sites, the $\mathrm{Spl}$ cis-elements are not conserved across species, suggesting that each species may utilize different combinations of transcription factors to achieve cAMP-dependent stimulation of the LH $\beta$ gene. Of note, a DNA-regulatory site for the CGAAT-binding factor NF-Y has been characterized in the bovine $\mathrm{LH} \beta$ gene promoter in the region of the Spl sites of the rat gene (Keri et al. 2000). NF-Y has been shown to contribute to cAMP-dependent regulation of both the rat fatty acid synthase and TIMP-2 genes (Roder et al. 1997, Zhong et al. 2000). It would be of interest to evaluate whether the NF-Y cis-acting elements mediate cAMP-responsiveness in the bovine $\mathrm{LH} \beta$ gene.

The orphan nuclear receptor SF-1 is known to alter LH $\beta$ gene expression independently, as well as through interactions with other transcription factors and with the PKC signaling system (Halvorson et al. 1996, 1998, 1999, Keri \& Nilson 1996, Dorn et al. 1999, Wolfe 1999). We now demonstrate that the presence of SF-1 augments cAMP-induced stimulation of the rat LH $\beta$ gene promoter activity when tested in SF-1-deficient $\mathrm{GH}_{3}$ cells. A similar observation has been reported for the equine LH $\beta$ gene in placental JEG3 cells (Heckert 2001). 
SF-1 is believed to be directly responsible for conferring cAMP-dependent transcription in a number of genes, although the mechanism by which this effect is achieved remains unclear (Lynch et al. 1993, Glemens et al. 1994, Michael et al. 1995, Zhang \& Mellon 1996, Carlone \& Richards 1997, Chau et al. 1997, Liu \& Simpson 1997, Jacob \& Lund 1998, Sandhoff et al. 1998, Aesoy et al. 2002). In a variety of studies in non-pituitary cells, neither hormonal nor pharmacological stimulation of the cAMP/PKA pathway increased steady-state SF-1 mRNA levels (Zhang \& Mellon 1996, Chau et al. 1997, Aesoy et al. 2002). Aesoy et al. (2002) have shown that prolonged forskolin treatment $(10 \mu \mathrm{M} \times 24 \mathrm{~h})$ increases SF-1 protein levels by decreasing SF-1 degradation in adrenocortical cells. We did not observe a forskolinmediated increase in gonadotrope-derived SF-1 protein (Fig. 7); however, we cannot rule out the possibility that a higher dose and/or longer treatment regimen would increase pituitary SF-1. Nevertheless, this response would not explain the ability of forskolin to induce $\mathrm{LH} \beta$ gene transcription in the $4 \mathrm{~h}$ time course demonstrated in our studies. Furthermore, the persistent cAMP response with mutation of the LH $\beta$-GSEs and the inability of a GSE-multimer construct to confer cAMPresponsiveness argue against a direct role for SF-1 or its cis-element (Fig. 5). Our results strongly suggest that cAMP-induced activation of the LH $\beta$ gene does not require SF-1 or its cis-elements; however, the presence of SF-1 does amplify the cAMP response, probably through known functional interactions with Egr-1 and Spl (Liu \& Simpson 1997, Halvorson et al. 1998, Kaiser et al. 2000).

The studies reported here clearly indicate the complexity of the molecular mechanisms which mediate cAMP-stimulated LH $\beta$ gene expression. Based on our data, the Egr-1 and Spl sites contribute nearly $75 \%$ of cAMP-responsiveness to the LH $\beta$ gene promoter; however, despite mutation of the only other identified cis-element in this gene (the Ptx/Otx element), we have been unable to account for the residual response. By sequence analysis, the LH $\beta$ gene lacks a classic cAMPresponse element. Furthermore, mutation of a putative AP-2-like site at position -84 does not alter cAMP-mediated LH $\beta$ promoter activity (data not shown). It will be of interest to attempt to identify any additional cAMP-responsive ciselements in future studies.
In conclusion, our results demonstrate that activation of the cAMP system by PACAP or forskolin increases LH $\beta$ gene promoter activity. The forskolin response is mediated via Egr-1 and Spl acting at their cognate DNA-binding sites in the rat $\mathrm{LH} \beta$ gene. Although not required for cAMP-responsiveness, SF-1 markedly augments cAMP-induced LH $\beta$ gene transcription. Of note, this mechanism is similar to a model proposed for GnRH/PKC-induced activation of the rat LH $\beta$ gene (Kaiser et al. 2000). We, therefore, propose that Spl, Egr-1 and SF-1 play critical roles in integrating the transcriptional response of the LH $\beta$-subunit gene to a variety of hormonal stimuli.

\section{Acknowledgements}

This work was supported by grants NIH R03 HD34692 and RO1 HD38089.

\section{References}

Acampora D, Mazan S, Tuorto F, Avantaggiato V, Tremblay JJ, Lazzaro D, di Carlo A, Mariano A, Macchia PE, Corte G et al. 1998 Transient dwarfism and hypogonadism in mice lacking Otx 1 reveal prepubescent stage-specific control of pituitary levels of GH, FSH and LH. Development 125 1229-1239.

Aesoy R, Mellgren G, Morohashi K \& Lund J 2002 Activation of cAMP-dependent protein kinase increases the protein level of steroidogenic factor-1. Endocrinology 143 295-303.

Ahlgren R, Suske G, Waterman MR \& Lund J 1999 Role of Spl in cAMP-dependent transcriptional regulation of the bovine CYP11A gene. Fournal of Biological Chemistry 274 19422-19428.

Andrews NC \& Faller DV 1991 A rapid micropreparation technique for extraction of DNA-binding proteins from limiting numbers of mammalian cells. Nucleic Acids Research 192499.

Attardi B \& Winters SJ 1998 Transcriptional regulation of the glycoprotein hormone alpha-subunit gene by pituitary adenylate cyclase-activating polypeptide (PACAP) in alphaT3-1 cells. Molecular and Cellular Endocrinology 137 97-107.

Barnhart KM \& Mellon PL 1994 The orphan nuclear receptor, steroidogenic factor-1, regulates the glycoprotein hormone $\alpha$-subunit gene in pituitary gonadotropes. Molecular Endocrinology 8 878-885.

Begeot M, Shetty U, Kilgore M, Waterman M \& Simpson E 1993 Regulation of expression of the CYP11A (P450 scc) gene in bovine ovarian luteal cells by forskolin and phorbol esters. fournal of Biological Chemistry 268 17317-17325.

Berg JM $1992 \mathrm{Spl}$ and the subfamily of zinc finger proteins with guanine-rich binding sites. PNAS 89 11109-11110.

Bernal-Mizrachi E, Wice B, Inoue H \& Permutt MA 2000 Activation of serum response factor in the depolarization induction of Egr-1 transcription in pancreatic islet beta-cells. Fournal of Biological Chemistry 275 25681-25689.

Borroni R, Liu Z, Simpson ER \& Hinshelwood MM 1997 A putative binding site for $\mathrm{Spl}$ is involved in transcriptional regulation of CYP17 gene expression in bovine ovary. Endocrinology $1382011-2020$. 
Bresson-Bepoldin L, Jacquot MC, Schlegel W \& Rawlings SR 1998 Multiple splice variants of the pituitary adenylate cyclase-activating polypeptide type 1 receptor detected by RT-PCR in single rat pituitary cells. Fournal of Molecular Endocrinology 21 109-120.

Burrin JM, Aylwin SJ, Holdstock JG \& Sahye U 1998 Mechanism of action of pituitary adenylate cyclase-activating polypeptide on human glycoprotein hormone alpha-subunit transcription in alphaT3-1 gonadotropes. Endocrinology 139 1731-1737.

Cao XM, Koski RA, Gashler A, McKiernan M, Morris CF, Gaffney R, Hay RV \& Sukhatme VP 1990 Identification and characterization of the Egr-1 gene product, a DNA-binding zinc finger protein induced by differentiation and growth signals. Molecular and Cellular Biology 10 1931-1939.

Carlone DL \& Richards JS 1997 Functional interactions, phosphorylation, and levels of $3^{\prime}, 5^{\prime}$-cyclic adenosine monophosphate-regulatory element binding protein and steroidogenic factor-1 mediate hormone-regulated and constitutive expression of aromatase in gonadal cells. Molecular Endocrinology 11 292-304.

Chau YM, Crawford PA, Woodson KG, Polish JA, Olson LM \& Sadovsky Y 1997 Role of steroidogenic-factor 1 in basal and 3',5'-cyclic adenosine monophosphate-mediated regulation of cytochrome $\mathrm{P} 450$ side-chain cleavage enzyme in the mouse. Biology of Reproduction $\mathbf{5 7}$ 765-771.

Chen J \& Iyengar R 1994 Suppression of ras-induced transformation of NIH 3T3 cells by activated Gas. Science $\mathbf{2 6 3}$ 1278-1281.

Christy BA, Lau LF \& Nathans D 1988 A gene activated in mouse 3T3 cells by serum growth factors encodes a protein with 'zinc finger' sequences. PNAS 85 7857-7861.

Clayton RN, Lalloz MRA, Salton SRJ \& Roberts JL 1991 Expression of luteinising hormone- $\beta$ subunit chloramphenicol acetyltransferase (LH- $\beta$-CAT) fusion gene in rat pituitary cells: induction by cyclic 3 -adenosine monophosphate (cAMP). Molecular and Cellular Endocrinology 80 193-202.

Clemens JW, Lala DS, Parker KL \& Richards JS 1994 Steroidogenic factor-1 binding and transcriptional activity of the cholesterol side-chain cleavage promoter in rat granulosa cells. Endocrinology 134 1499-1508.

Crawford PA, Polish JA, Ganpule G \& Sadovsky Y 1997 The activation function-2 hexamer of steroidogenic factor-1 is required, but not sufficient for potentiation by SRC-1. Molecular Endocrinology 11 1626-1635.

deWet JR, Wood KV, DeLuca M, Helinski DR \& Subramani S 1987 Firefly luciferase gene: structure and expression in mammalian cells. Molecular and Cellular Biology 7 725-737.

Dorn C, Ou Q, Svaren J, Crawford PA \& Sadovsky Y 1999 Activation of luteinizing hormone beta gene by gonadotropin-releasing hormone requires the synergy of early growth response-1 and steroidogenic factor-1. Fournal of Biological Chemistry 274 13870-13876.

Duan WR, Ito M, Park Y, Maizels ET, Hunzicker-Dunn M \& Jameson JL 2002 GnRH regulates early growth response protein 1 transcription through multiple promoter elements. Molecular Endocrinology 16 221-233.

Edlund T, Walker MD, Barr PJ \& Rutter WJ 1985 Cell specific expression of the rat insulin gene: evidence for a role of two distinct 5' flanking elements. Science 230 912-916.

Espey LL, Ujioka T, Russell DL, Skelsey M, Vladu B, Robker RL, Okamura H \& Richards JS 2000 Induction of early growth response protein-1 gene expression in the rat ovary in response to an ovulatory dose of human chorionic gonadotropin. Endocrinology $1412385-2391$.

Fujii Y, Okada Y, Moore JP Jr, Dalkin AC \& Winters SJ 2002 Evidence that PACAP and GnRH down-regulate follicle-stimulating hormone-beta mRNA levels by stimulating follistatin gene expression: effects on folliculostellate cells, gonadotrophs and LbetaT2 gonadotroph cells. Molecular and Cellular Endocrinology 192 55-64.

Garrel G, McArdle CA, Hemmings BA \& Counis R 1997 Gonadotropin-releasing hormone and pituitary adenylate cyclase-activating polypeptide affect levels of cyclic adenosine $3^{\prime}, 5^{\prime}$-monophosphate-dependent protein kinase A (PKA) subunits in the clonal gonadotrope $\alpha \mathrm{T} 3-1$ cells: evidence for cross-talk between PKA and protein kinase C pathways. Endocrinology 138 2259-2266.

Halvorson LM, Kaiser UB \& Chin WW 1996 Stimulation of luteinizing hormone $\beta$ gene promoter activity by the orphan nuclear receptor, steroidogenic factor-1. Fournal of Biological Chemistry 271 6645-6650.

Halvorson LM, Ito M, Jameson JL \& Chin WW 1998 Steroidogenic factor-1 and early growth response protein 1 act through two composite DNA binding sites to regulate luteinizing hormone $\beta$-subunit gene expression. Journal of Biological Chemistry 273 $14712-14720$.

Halvorson LM, Kaiser UB \& Chin WW 1999 The protein kinase C system acts through early growth response protein 1 to increase LH $\beta$ gene expression in synergy with steroidogenic factor-1. Molecular Endocrinology 13 106-116.

Heckert LL 2001 Activation of the rat follicle-stimulating hormone receptor promoter by steroidogenic factor 1 is blocked by protein kinase $\mathrm{A}$ and requires upstream stimulatory factor binding to a proximal E box element. Molecular Endocrinology 15 704-715.

Hezareh M, Journot L, Bepoldin L, Schlegel W \& Rawlings SR 1996 PACAP/VIP receptor subtypes, signal transducers, and effectors in pituitary cells. Annals of the New York Academy of Sciences 805 315-327 [discussion 327-328].

Ingraham HA, Lala DS, Ikeda Y, Luo X, Shen WH, Nachtigal MW, Abbud R, Nilson JH \& Parker KL 1994 The nuclear receptor steroidogenic factor 1 acts at multiple levels of the reproductive axis. Genes and Development 8 2302-2312.

Jackson SP, MacDonald JJ, Lees-Miller S \& Tjian R 1990 GC box binding induces phosphorylation of $\mathrm{Spl}$ by a DNA-dependent protein kinase. Cell 63 155-165.

Jacob AL \& Lund J 1998 Mutations in the activation function-2 core domain of steroidogenic factor-1 dominantly suppresses PKA-dependent transactivation of the bovine CYP17 gene. Fournal of Biological Chemistry 273 13391-13394.

Jameson JL, Chin WW, Hollenberg AN, Chang AS \& Habener JF 1984 The gene encoding the $\beta$-subunit of rat luteinizing hormone. fournal of Biological Chemistry 259 15474-15480.

Kaiser UB, Katzenellenbogen RA, Conn PM \& Chin WW 1994 Evidence that signalling pathways by which thyrotropin-releasing hormone and gonadotropin-releasing hormone act are both common and distinct. Molecular Endocrinology 8 1038-1048.

Kaiser UB, Sabbagh E, Chen MT, Chin WW \& Saunders BD $1998 a$ Spl binds to the rat LH $\beta$ gene promoter and mediates GnRH-stimulated expression of the LH $\beta$ subunit gene. Fournal of Biological Chemistry 273 12943-12951.

Kaiser UB, Sabbagh E, Saunders BD \& Chin WW $1998 b$ Identification of cis-acting deoxyribonucleic acid elements that mediate gonadotropin-releasing hormone stimulation of the rat luteinizing hormone $\beta$-subunit gene. Endocrinology 139 2443-2451.

Kaiser UB, Halvorson LM \& Chen MT 2000 Spl, steroidogenic factor 1 (SF-1), and early growth response protein 1 (Egr-1) binding sites form a tripartite gonadotropin-releasing hormone response element in the rat luteinizing hormone-b gene promoter: an integral role for SF-1. Molecular Endocrinology 14 1235-1245.

Keri RA \& Nilson JH 1996 A steroidogenic factor-1 binding site is required for activity of the luteinizing hormone $\beta$ subunit promoter in gonadotropes of transgenic mice. Fournal of Biological Chemistry 271 10782-10785. 
Keri RA, Bachmann DJ, Behrooz A, Herr BD, Ameduri RK, Quirk CG \& Nilson JH 2000 An NF-Y binding site is important for basal, but not gonadotropin-releasing hormone-stimulated, expression of the luteinizing hormone $\beta$ subunit gene. Fournal of Biological Chemistry 275 13082-13088.

Kim KE, Day KH, Howard P, Salton SRJ, Roberts JL \& Maurer RA 1990 DNA sequences required for expression of the LH $\beta$ promoter in primary cultures of rat pituitary cells. Molecular and Cellular Endocrinology 74 101-107.

Kuphal D, Janovick JA, Kaiser UB, Chin WW \& Conn PM 1994 Stable transfection of $\mathrm{GH}_{3}$ cells with rat gonadotropin-releasing hormone receptor complementary deoxyribonucleic acid results in expression of a receptor coupled to cyclic adenosine

$3^{\prime}, 5^{\prime}$-monophosphate-dependent prolactin release via a G-protein. Endocrinology 135 315-320.

Lala DS, Rice DA \& Parker KL 1992 Steroidogenic factor 1, a key regulator of steroidogenic enzyme expression, is the mouse homolog of Fushi tarazu-factor 1. Molecular Endocrinology 6 1249-1258.

Lamonerie T, Tremblay JJ, Lanctot C, Therrien M, Gauthier Y \& Drouin J 1996 Ptxl, a bicoid-related homeo box transcription factor involved in transcription of the pro-opiomelanocortin gene. Genes and Development 10 1284-1295.

Lanctot C, Lamolet B \& Drouin J 1997 The bicoid-related homeoprotein Ptxl defines the most anterior domain of the embryo and differentiates posterior from anterior lateral mesoderm. Development 124 2807-2817.

Lee SL, Sadovsky Y, Swirnoff AH, Polish JA, Goda P, Gavrilina G \& Milbrandt J 1996 Luteinizing hormone deficiency and female infertility in mice lacking the transcription factor NGFI-A (Egr-1). Science 273 1219-1221.

Liu F, Usui I, Evans LG, Austin DA, Mellon PL, Olefsky JM \& Webster NJ 2002 Involvement of both $\mathrm{G}(\mathrm{q} / 11)$ and $\mathrm{G}(\mathrm{s})$ proteins in gonadotropin-releasing hormone receptor-mediated signaling in L beta T2 cells. Fournal of Biological Chemistry 277 32099-32108.

Liu Z \& Simpson ER 1997 Steroidogenic factor 1 (SF-1) and Spl are required for regulation of bovine CYP11A gene expression in bovine luteal cells and adrenal Yl cells. Molecular Endocrinology 11 127-137.

Liu Z \& Simpson ER 1999 Molecular mechanism for cooperation between Spl and steroidogenic factor-1 (SF-1) to regulate bovine CYP11A gene expression. Molecular and Cellular Endocrinology 153 183-196.

Luo X, Ikeda Y \& Parker KL 1994 A cell-specific nuclear receptor is essential for adrenal and gonadal development and sexual differentiation. Cell 77 481-490.

Lynch JP, Lala DS, Peluso JJ, Luo W, Parker KL \& White BA 1993 Steroidogenic factor 1 , an orphan nuclear receptor, regulates the expression of the rat aromatase gene in gonadal tissues. Molecular Endocrinology 7 776-786.

McArdle CA, Poch A, Schomerus E \& Kratzmeier M 1994 Pituitary adenylate cyclase-activating polypeptide effects in pituitary cells; modulation by gonadotropin-releasing hormone in alpha T3-1 cells. Endocrinology 134 2599-2605.

Michael MD, Kilgore MW, Morohashi K \& Simpson ER 1995 Ad4 $\mathrm{BP} / \mathrm{SF}-1$ regulates cyclic AMP-induced transcription from the proximal promoter (PII) of the human aromatase P450 (CYP19) gene in the ovary. Fournal of Biological Chemistry 270 13561-13566.

Miyata A, Arimura A, Dahl RR, Minamino N, Uehara A, Jiang L, Culle DH \& Coy DH 1989 Isolation of a novel 38 residue hypothalamic polypeptide which stimulates adenylate cyclase in pituitary cells. Biochemical and Biophysical Research Communications 164 $567-574$.

Nordeen S 1988 Luciferase reporter gene vectors for analysis of promoters and enhancers. Bio Techniques $6454-458$.

Ortmann O, Asmus W, Diedrich K, Schulz K-D \& Emons G 1999 Interactions of ovarian steroids with pituitary adenylate cyclase-activating polypeptide and $\mathrm{GnRH}$ in anterior pituitary cells. European Fournal of Endocrinology 140 207-214.

Park D, Kim C, Cheon M, Kim K \& Ryu K 1997 cAMP and protein kinase $\mathrm{C}$ elevate $\mathrm{LH}$ beta mRNA levels by activating transcription rather than stabilizing mRNA in rat pituitary cells. Molecules and Cells 7 98-103.

Pinter JH, Janovick JA \& Conn PM 1999 Gonadotropin-releasing hormone receptor concentration differentially regulates intracellular signaling pathways in $\mathrm{GH}_{3}$ cells. Pituitary 2 181-190.

Pisegna JR \& Wank SA 1996 Cloning and characterization of the signal transduction of four splice variants of the human pituitary adenylate cyclase activating polypeptide receptor. Evidence for dual coupling to adenylate cyclase and phospholipase C. Fournal of Biological Chemistry 271 17267-17274.

Quirk CG, Lozada KL, Keri RA \& Nilson JH 2001 A single Pitx 1 binding site is essential for activity of the LHßeta promoter in transgenic mice. Molecular Endocrinology 15 734-746.

Roder K, Wolf SS, Beck KF, Sickinger S \& Schweizer M 1997 NF-Y binds to the inverted CCAAT box, an essential element for cAMP-dependent regulation of the rat fatty acid synthase (FAS) gene. Gene 184 21-26.

Rosenberg SB \& Mellon PL 2002 An Otx-related homeodomain protein binds an LHßeta promoter element important for activation during gonadotrope maturation. Molecular Endocrinology 16 1280-1298.

Sandhoff TW, Hales DB, Hales KH \& McLean MP 1998 Transcriptional regulation of the rat steroidogenic acute regulatory protein gene by steroidogenic factor 1. Endocrinology 139 $4820-4831$.

Saunders BD, Sabbagh E, Chin WW \& Kaiser UB 1998 Differential use of signal transduction pathways in the gonadotropin-releasing hormone-mediated regulation of gonadotropin subunit gene expression. Endocrinology 139 1835-1843.

Schomerus E, Poch A, Bunting R, Mason WT \& McArdle CA 1994 Effects of pituitary adenylate cyclase-activating polypeptide in the pituitary: activation of two signal transduction pathways in the gonadotrope-derived $\alpha$ T3-1 cell line. Endocrinology 134 315-323.

Stanislaus D, Janovick JA, Jennes L, Kaiser UB, Chin WW \& Conn PM 1994 Functional and morphological characterization of four cell lines derived from $\mathrm{GH}_{3}$ cells stably transfected with gonadotropin-releasing hormone receptor complementary deoxyribonucleic acid. Endocrinology 135 2220-2227.

Starzec A, Counis R \& Jutisz M 1986 Gonadotropin-releasing hormone stimulates the synthesis of the polypeptide chains of luteinizing hormone. Endocrinology 119 561-565.

Starzec A, Jutisz M \& Counis R 1989 Cyclic adenosine monophosphate and phorbol ester, like gonadotropin-releasing hormone, stimulate the biosynthesis of luteinizing hormone polypeptide chains in a nonadditive manner. Molecular Endocrinology 3 618-624.

Stojilkovic SS, Reinhart J \& Catt KJ 1994 Gonadotropin-releasing hormone receptors: structure and signal transduction pathways. Endocrine Reviewes 15 462-499.

Suen C-S, Yen PM \& Chin WW 1994 In vitro transcriptional studies of the roles of the thyroid hormone (T3) response elements and minimal promoters in T3-stimulated gene transcription. Fournal of Biological Chemistry 269 1314-1322.

Sukhatme VP, Kartha S, Toback FG, Taub R, Hoover RG \& Tsai-Morris C 1987 A novel early growth response gene rapidly induced by fibroblast epithelial cell and lymphocyte mitogens. Oncogene Research 1 343-355.

Tai TC, Morita K \& Wong DL 2001 Role of Egr-1 in cAMP-dependent protein kinase regulation of the phenylethanolamine $\mathrm{N}$-methyltransferase gene. Fournal of Neurochemistry 76 1851-1859.

Topilko P, Schneider-Maunoury S, Levi G, Trembleau A, Gourdji D, Driancourt M-A, Rao GV \& Charnay P 1997 Multiple 
pituitary and ovarian defects in Krox-24 (NGFI-A, Egr-1)-targeted mice. Molecular Endocrinology 12 107-122.

Tremblay JJ \& Drouin J 1999 Egr-1 is a downstream effector of GnRH and synergizes by direct interaction with Ptxl and SF-1 to enhance luteinizing hormone beta gene transcription. Molecular and Cellular Biology 19 2567-2576.

Tremblay JJ, Lanctot C \& Drouin J 1998 The pan-pituitary activator of transcription, Ptxl (pituitary homeobox 1), acts in synergy with SF-1 and Pitl and is an upstream regulatory of the Lim-homeodomain gene Lim3/Lhx3. Molecular Endocrinology 12 428-441.

Tremblay JJ, Marcil A, Gauthier Y \& Drouin J 1999 Ptxl regulates SF-1 activity by an interaction that mimics the role of the ligand-binding domain. EMBO fournal 18 3431-3441.

Tsujii T \& Winters SJ 1995 Effects of pulsatile pituitary adenylate cyclase activating polypeptide (PACAP) on gonadotropin secretion and subunit mRNA levels in perifused rat pituitary cells. Life Sciences 56 1103-1111.

Tsujii T, Ishizaka K \& Winters SJ 1994 Effects of pituitary adenylate cyclase activating polypeptide (PACAP) on gonadotropin secretion and subunit mRNAs in perifused rat pituitary cells. Endocrinology 135 826-833.

Turgeon JL, Kimura Y, Waring DW \& Mellon PL 1996 Steroid and pulsatile gonadotropin-releasing hormone $(\mathrm{GnRH})$ regulation of luteinizing hormone and GnRH receptor in a novel gonadotrope cell line. Molecular Endocrinology 10 439-450.

Vasilyev VV, Lawson MA, Dipaolo D, Webster NJ \& Mellon PL 2002 Different signaling pathways control acute induction versus long-term repression of LHßeta transcription by GnRH. Endocrinology 143 3414-3426.

Venepally P \& Waterman MR 1995 Two Spl-binding sites mediate cAMP-induced transcription of the bovine CYP11A gene through the protein kinase A signaling pathway. Fournal of Biological Chemistry $27025402-25410$.

Weck J, Fallest PC, Pitt LK \& Shupnik MA 1998 Differential gonadotropin-releasing hormone stimulation of rat luteinizing hormone subunit gene transcription by calcium influx and mitogen-activated protein kinase-signaling pathways. Molecular Endocrinology 12 451-457.
Weck J, Anderson AC, Jenkins S, Fallest PC \& Shupnik MA 2000 Divergent and composite gonadotropin-releasing hormone-responsive elements in the rat luteinizing hormone subunit genes. Molecular Endocrinology 14 472-485.

Winters SJ, Dalkin AC \& Tsujii T 1997 Evidence that pituitary adenylate cyclase activating polypeptide suppresses follicle-stimulating hormone-beta messenger ribonucleic acid levels by stimulating follistatin gene transcription. Endocrinology 138 4324-4329.

Wolfe MW 1999 The equine luteinizing hormone beta-subunit promoter contains two functional steroidogenic factor-1 response elements. Molecular Endocrinology 13 1497-1510.

Wolfe MW \& Call GB 1999 Early growth response protein 1 binds to the luteinizing hormone-beta promoter and mediates gonadotropin-releasing hormone-stimulated gene expression. Molecular Endocrinology 13 752-763.

Woodson KG, Crawford PA, Sadovsky Y \& Milbrandt J 1997 Characterization of the promoter of SF-1, an orphan nuclear receptor required for adrenal and gonadal development. Molecular Endocrinology 11 117-126.

Yoshino M, Mizutani T, Yamada K, Tsuchiya M, Minegishi T, Yazawa T, Kawata H, Sekiguchi T, Kajitani T \& Miyamoto K 2002 Early growth response gene-1 regulates the expression of the rat luteinizing hormone receptor gene. Biology of Reproduction 66 $1813-1819$

Zhang P \& Mellon SH 1996 The orphan nuclear receptor steroidogenic factor-1 regulates the cyclic adenosine $3^{\prime}, 5^{\prime}$-monophosphate-mediated transcriptional activation of rat cytochrome P450c17 (17a-hydroxylase/c17-20 lyase). Molecular Endocrinology 10 147-158.

Zhong ZD, Hammani K, Bae WS \& DeClerck YA 2000 NF-Y and Spl cooperate for the transcriptional activation and cAMP response of human tissue inhibitor of metalloproteinases-2. Fournal of Biological Chemistry 275 18602-18610.

Received 4 June 2003

Accepted 8 October 2003 